\title{
The impact of FSH receptor polymorphism on time-to-pregnancy: a cross-sectional single-centre study
}

\author{
Birute Zilaitiene ${ }^{1 *}$, Marius Dirzauskas ${ }^{1}$, Rasa Verkauskiene ${ }^{1}$, Rytas Ostrauskas ${ }^{1}$, Joerg Gromoll ${ }^{2}$ \\ and Eberhard Nieschlag ${ }^{2}$
}

\begin{abstract}
Background: Single nucleotide polymorphism of the follicle-stimulating hormone (FSH) receptor (FSHR) is an important marker of ovarian function. However, its role in female fecundity remains debatable. The aim of the study to assess the relationship of FSHR polymorphism of Serine/Serine, Asparagine/Asparagine and Asparagine/ Serine variants directly against the time-to-pregnancy (TTP) in women.

Methods: Data were collected from 291 consecutive selected post-partum Caucasians using this criterion: ethnicity, age between 21 and 34-year-old new mothers and, 0-3 days after delivery of newborns in the Klaipeda University Hospital, Lithuania. Questionnaires on factors associated with conception were given to patients, and blood samples were collected for genomic DNA extractions as well as for analysis of follicle-stimulating hormone receptor gene polymorphism. Odds ratios (OR) and 95\% confidence intervals (Cl) for time-to-pregnancy were estimated by multivariate logistic regression. Women with unplanned pregnancies and those who received assisted reproductive technologies were not included in the study.
\end{abstract}

Results: After adjustment for other possible factors, increased risk for time-to-pregnancy of 12 or more months was associated with: Serine/Serine polymorphism variant ( $O R=1.38,95 \% \mathrm{Cl} 1.56-2.71, p=0.007)$, age of 30 or more years $(\mathrm{OR}=1.95,95 \% \mathrm{Cl} 1.25-2.71, p=0.015)$, gynaecological diseases in the past $(\mathrm{OR}=2.21,95 \% \mathrm{Cl} 1.12-5.74, p=0.027)$, prior contraception use $(\mathrm{OR}=1.87,95 \% \mathrm{Cl} 1.14-3.64, p=0.016)$, and fertility problems in the past $(\mathrm{OR}=1.57,95 \% \mathrm{Cl}$ $1.16-4.76, p=0.019)$

Conclusion: The results suggest a possible relationship of FSH receptor gene Serine/Serine variant for the lower possibility of conception during the first 12 months of planned conception.

Keywords: Time to pregnancy, FSH receptor haplotypes, FSH receptor polymorphism

\section{Background}

Fecundity is the wonderful biological ability to produce abundant healthy offspring and is affected by genetic and environmental factors [1]. If pregnancy is planned, fertility may be expressed as time-to-pregnancy (TTP) [2]. TTP is defined as the number of contraceptive-free cycles needed to conceive [3]. A TTP greater than 12 months allocates the infertility status $[4,5]$. Usually

\footnotetext{
* Correspondence: birute.zilaitiene@lsmuni.lt

${ }^{1}$ Institute of Endocrinology, Lithuanian University of Health Sciences, 50009

Kaunas, Lithuania

Full list of author information is available at the end of the article
}

trying to conceive in the first year succeeds for $\sim 85 \%$ of cases [6].

Impaired fertility is inherited and may be due to inactivating mutations in the gonadotropin and gonadotropin receptor genes [7, 8]. Recent genetic studies have revealed that the pathogenesis of subfertility or infertility can be due to mutations in the follicle-stimulating hormone receptor (FSHR) gene [9]. While mutations affecting FSHR are sporadic; polymorphism of the FSHR gene seems to be a common phenomenon [9]. FSHR inactivating mutations may cause primary or secondary amenorrhea, infertility, and premature ovarian failure [10]; whereas activating mutations can predispose to ovarian hyperstimulation syndrome,

(c) The Author(s). 2018 Open Access This article is distributed under the terms of the Creative Commons Attribution 4.0 International License (http://creativecommons.org/licenses/by/4.0/), which permits unrestricted use, distribution, and reproduction in any medium, provided you give appropriate credit to the original author(s) and the source, provide a link to the Creative Commons license, and indicate if changes were made. The Creative Commons Public Domain Dedication waiver (http://creativecommons.org/publicdomain/zero/1.0/) applies to the data made available in this article, unless otherwise stated. 
as a consequence of exogenous FSH administration, or to a spontaneous onset [10-12].

In-vitro studies have shown that the A allele at the 29th position in the $5^{\prime}$ untranslated region of the FSHR gene is associated with impaired transcriptional activity [13]. The polymorphism at position 29 in the promoter of the FSHR gene may contribute to the reduced receptor expression [14]. The FSHR shows nucleotide polymorphisms in the promoter and in exon 10 [15]. The single nucleotide polymorphisms in exon 10 results in four discrete allelic variants characterized by the amino acid combinations: threonine (Thr)307-asparagine (Asn)680, alanine (Ala)307Serine (Ser)680, Ala307-Asn680 and Thr307-Ser680 [15]. The first two allelic variants are very frequent in the Caucasian population [15]. At position 680, three FSH receptor variants are possible: Asn/Asn, Asn/Ser, and Ser/Ser; however, Ser/Ser-680 predominates in the studied infertile population [16].

The studies on FSHR polymorphism, performed on patients undergoing in-vitro fertilisation procedures show that women homozygous for the Ser680 variant have higher follicular FSH levels and longer follicular phase length, which suggest a lower sensitivity to FSH. Thus the homozygous Ala307-Ser680 variant is associated with a higher amount of FSH required for ovarian stimulation in women undergoing assisted reproduction [15]. This suggests that the FSHR genotype can influence the ovarian response to FSH stimulation $[17,18]$. However, there are studies where this association was not confirmed [19, 20].

FSH is responsible for follicular maturation and for the length and stability of the menstrual cycle [21]. A longer cycle may be associated with more difficulties in conception; women who have the FSHR gene Asn (Asparagine) exchanged for Ser (Serine) at codon 680 have statistically proven longer menstrual cycles [22].

Despite the numerous publications on the FSHR polymorphism impact on women's reproductive function; an FSHR polymorphic relationship to TTP has not yet been studied. Here we aimed to assess the relationship of the FSHR polymorphism Serine/Serine, Asparagine/Asparagine and Asparagine/Serine variants on TTP in a sample of Lithuanian women.

\section{Methods}

\section{Subjects}

Klaipeda is the third largest city in Lithuania and has one obstetric department that performs approximately 3500 deliveries per year from all parts of the west region of Lithuania. Between March 2008 and May 2008, 291 consecutive selected 21-34-year-old (mediana [25-75\%] - 27.0 [24.0-31.0] years) women who conceived naturally and delivered babies at the Klaipeda University Hospital were invited to participate in the study 0-3 days after delivery. This time interval was chosen because it allowed for the accurate recall of the time period preceding conception, and it was a time point at which the delivery outcome was already known. All selected women had planned pregnancies that were achieved without using assisted reproductive technologies. In $49.17 \%$ of cases women were nulliparous, the rest of them - multiparous. Prior to pregnancy planning, 67 (22.26\%) women used hormonal contraception. Women were asked to complete a standardised questionnaire. It included questions concerning age, height, weight before pregnancy, the menstrual cycle, socioeconomic factors, lifestyle, sexual behaviour, and some other factors. The regular menstrual cycle was defined as $28 \pm 7$ days and this definition was explained to study participants. Women with irregular menstrual cycles were asked to report if the majority of their cycles are $<21$ days or $>$ 35 days. Only one participant reported irregular cycles < 21 days, so, she was excluded from the final analysis. The questions regarding gynaecological diseases were asked separately for non-infectious and infectious diseases. Women with unplanned pregnancies and those who received assisted reproductive technologies were not included in the study. However, women who get another infertility treatment, e.g. ovulation induction, treatment of infections - were enrolled into the study.

\section{DNA sampling}

A venous blood sample was drawn for DNA extraction from all 291participants.

$D N A$ extraction was performed in a certificated "SORPO" laboratory of Thermo Fisher Scientific Inc. in Vilnius, Lithuania. DNA samples froze at-20 ${ }^{\circ} \mathrm{C}$; were sent to the University of Munster in Germany. There are two known polymorphisms of clinical relevance in the hormone (FSH) receptor exon 10: Ala or Thr at position 307 (dbSNP numbers 6165), and Asn or Ser at position 680 (dbSNP numbers 6166). These give rise to two discrete allelic variants: $\mathrm{Thr}^{307} / \mathrm{Asn}^{680}$ and $\mathrm{Ala}^{307} / \mathrm{Ser}^{680}$. The allelic variants at codon 307 and 680 are almost invariably associated, therefore codon 680 was assessed, and all women were classified as homozygous $(\mathrm{Ser} / \mathrm{Ser}$ or $A s n / A s n)$ or heterozygous (Asn/Ser).

Genomic $D N A$ was extracted from peripheral blood using a FlexiGene DNA extraction kit (QIAGEN, Hilden, Germany) according to the manufacturer's instruction. All samples were screened for the single nucleotide polymorphism (SNP) at position 2039 (codon 680) of exon 10 by the TaqMan allelic discrimination assay while using the ABI Prism 7000 sequence detection system (Applied Biosystems, Darmstadt, Germany). The probes (SNP indicated in bold lower case letters) were 5'-AGAGTCACC AgTGGTT-3' (6-carboxyfluorescein fluorescence) and 5'-AGTCACCAaTGGTTC-3' (VIC fluorescence). The 
primers were $5^{\prime}$-AAGGAATGGCCACTGCTCTTC-3' (forward) and 5'-GGGCTAAATGACTTAGAGGGACAA $-3^{\prime}$ (reverse). Each polymerase chain reaction (PCR) $(25 \mu \mathrm{l})$ contained: $2 \mu \mathrm{l}$ DEPC-treated water, $12.5 \mu \mathrm{l}$ Universal master mix, $0.25 \mu \mathrm{l}$ of each probe, and $4.5 \mu \mathrm{l}$ of each primer $(5 \mathrm{pmol})$. Using the TaqManassay, PCR was performed in two steps: absolute quantification and allelic discrimination. For absolute quantification, the cycles were as follows: stage 1: Probe binding at $50{ }^{\circ} \mathrm{C}$ for 2 mins (1 cycle); stage 2: denaturation at $95{ }^{\circ} \mathrm{C}$ for $10 \mathrm{mins}$ (1 cycle), followed by 35 cycles at $95{ }^{\circ} \mathrm{C}$ for $15 \mathrm{~s}$; stage $3: 60{ }^{\circ} \mathrm{C}$ for $1 \mathrm{~min}$. Whereas the allelic discrimination assay took $1 \mathrm{~min}$ at $60{ }^{\circ} \mathrm{C}$.

\section{Statistical analysis}

Analyses were performed using SPSS 17.0 software. Women who conceived after $\geq 12$ months of trying were classified as the risk group. The normality of distribution was tested using the Kolmogorov-Smirnov test. Student's ( $t$ ) criterion was used for comparison of means for normal distributions, and the Mann-Whitney (U) test was used in skewed distributions. In order to determine the difference between more than two groups; parametric and nonparametric dispersive analysis with ANOVA and Kruskal-Wallis test was performed. Bonferroni test was performed by comparing multiple pairs. For evaluating dependence between qualitative features $X^{2}$ criterion was used. Results were presented as mean $(\mathrm{M}) \pm$ standard deviation (SD) or $\mathrm{n}(\%)$. Biological, social, demographic, economic, sexual behaviour, genetic, living, working and environmental confounders variables were retaining in models. Univariate analysis of the OR for each variable was taken initially. Multivariate logistic regression step-wise enter method model was used to estimate the most important relationship factors. Odds ratios (OR) and $95 \%$ confidence intervals (CI) for time-to-pregnancy was calculated. The limit of significance was defined as a two-sided $p$-value of $<0.05$.

The study was approved by the Lithuanian Bioethics Committee (21/12/2006 No. 59/2). The aim of the survey protocol was carefully explained to each subject of study entry, and a written informed consent was obtained.

\section{Results}

\section{FSHR genetic variants}

The mean TTP in the study group of 291 woman was $5.3 \pm 10.9$ (mediana [25-75\%]: 1.0 [1.0-5.0]) months. The main demographic, social, lifestyle and other characteristics of the participants are shown in Table 1.

During FSH receptor genotype analysis three groups of $A s n^{680}$ and $\mathrm{Ser}^{680}$ variation were detected: 101 (34.7\%) of cases were found to be homozygous for $A s n^{680}$ (Asn/ Asn -group), 148 (50.9\%) heterozygous for $A s n^{680}$ and $\mathrm{Ser}^{680}$ (Asn/Ser -group), and 42 (14.4\%) homozygous for
$\operatorname{Ser}^{680}$ (Ser/Ser -group). Median TTP in the Asn/Asn participant group was 1.0 [95\% CI 1.0-4.0] months, in the Asn/Ser group: 1.0 [1.0-3.75] months, and in the Ser/Ser group: 7.0 [1.0-15.25] months. Furthermore, these differences of were significant $(p<0.03)$.

Women having the Ser/Ser polymorphism variant had significantly longer TTP compared to those bearing variants $A s n / A s n$ and $A s n / \operatorname{Ser}(p=0.01$ and $\mathrm{p}=0.01$ respectively) (Fig. 1). When comparing Asn/Asn and Asn/Ser groups, no significant differences in TTP were found.

In the comparison between the Ser/Ser and the Asn/ Asn FSHR genetic variants, the risk for a TTP of 12 months or longer is higher for those women with the variant Ser/Ser (Table 2). The highest sensitivity and positive prognostic value, along with the lowest false positive rate $\alpha$, occur when comparing the Ser/Ser genetic variant to $A s n / A s n$. Thus this combination has the highest effect size for estimating TTP (Table 3 ).

Women with the Ser/Ser polymorphism had irregular menstrual cycles (> 35 days) more frequently when compared to other genetic variants $\left(\mathrm{x}^{2}=20.2 ; \mathrm{df}=2 ; p<\right.$ 0.001) (Table 1). The highest odds ratio is found when comparing Ser/Ser and Asn/Ser FSHR genetic variants, and the risk for having irregular menstrual cycle is 4 times higher in women with the Ser/Ser variant.

\section{Risk factors for a TTP of 12 or more months for the women in the study group}

Logistic regression methods were used to explore potential risk factors for longer TTP. Proportional differences were analysed to compare data of women who conceived up till 12 months with data of women who conceived at 12 or more months. Meanwhile, other factors possibly having an influence on TTP were also checked in this study. Most of the study participants were living in the city, in their own residences, as couples had higher education, higher monthly salary, worked, didn't smoke, and drank coffee (Table 1). Only a few of cases were obese (5.50\%), had previous gynaecological diseases (15.46\%), or fertility problems (5.84\%). Respondents with alcohol consumption reported stress during pregnancy planning and pregnancy quantity; both divided up equally. The use of folic acid or other food supplements was surprisingly low (24.40 and $33.33 \%$ respectively). TTP of $\geq 12$ months was reported significantly more often by women whose age was 30 years or more $(p=0.048)$, who had irregular menstrual cycles $(p<0.001)$, previous fertility problems and/or gynaecological diseases $(p<0.001$ both), used any contraception prior to pregnancy planning $(p=0.004)$, drank coffee $(\mathrm{p}=0.048)$, consumed other food supplements $(\mathrm{p}=0.004)$, lived within $<10 \mathrm{~km}$ from factories $(\mathrm{p}=0.04)$, had low physical activity $(p=$ $0.044)$, and the SER/SER polymorphism variant $(p<$ 0.001). Unadjusted univariate $\mathrm{OR}$ and $95 \% \mathrm{CI}$ for 
Table 1 Main characteristics of study participants

\begin{tabular}{|c|c|c|c|c|c|c|}
\hline \multirow[t]{3}{*}{ Criteria } & \multicolumn{6}{|c|}{ FSHR genetic variant } \\
\hline & \multicolumn{2}{|c|}{ Asn/Asn } & \multicolumn{2}{|c|}{ Asn/Ser } & \multicolumn{2}{|c|}{ Ser/Ser } \\
\hline & $\bar{n}$ & $\begin{array}{l}\% \text { or Median } \\
(25-75 \% \mathrm{Cl})\end{array}$ & $\bar{n}$ & $\begin{array}{l}\% \text { or Median } \\
(25-75 \% \mathrm{Cl})\end{array}$ & $\bar{n}$ & $\begin{array}{l}\text { \% or Median } \\
(25-75 \% \mathrm{Cl})\end{array}$ \\
\hline Participants & 101 & 34.7 & 148 & 50.9 & 42 & 14.4 \\
\hline Mean age (years) & & $27.4 \pm 5.9$ & & $27.2 \pm 5.5$ & & $27.9 \pm 5.0$ \\
\hline Median body mass index $\left(\mathrm{kg} / \mathrm{m}^{2}\right)$ & & $21.4(19.8-24.1)$ & & $22.3(20.0-24.1)$ & & $\begin{array}{l}21.5 \\
(20.1-23.1)\end{array}$ \\
\hline Median TTP (month) & & $1.0(1.0-4.0)^{*}$ & & $1.0(1.0-3.8)^{*}$ & & $\begin{array}{l}7.0 \\
(1.0-15.3)\end{array}$ \\
\hline TTP $<12$ month & 92 & $91.1^{*}$ & 133 & $89.9^{*}$ & 27 & 64.3 \\
\hline TTP $\geq 12$ month & 9 & 8.9 & 15 & 10.1 & 15 & 35.7 \\
\hline Nuliparous & 48 & 47.5 & 75 & 50.7 & 25 & 59.5 \\
\hline Multiparous & 53 & 52.5 & 73 & 49.3 & 17 & 40.5 \\
\hline Living in the city & 76 & 75.3 & 115 & 77.7 & 35 & 83.3 \\
\hline Living in the country & 25 & 24.7 & 33 & 22.3 & 7 & 16.7 \\
\hline Education lower than college & 37 & 36.6 & 63 & 42.6 & 14 & 33.3 \\
\hline College education and higher & 64 & 63.4 & 85 & 57.4 & 28 & 66.7 \\
\hline Salary $<560$ Euro/month & 34 & 33.7 & 36 & 24.3 & 11 & 26.2 \\
\hline Salary $\geq 560$ Euros/month & 67 & 66.3 & 112 & 75.7 & 31 & 73.8 \\
\hline Smoking & 28 & 27.7 & 28 & 18.9 & 6 & 14.3 \\
\hline Alcohol consumers & 51 & 50.5 & 74 & 50.0 & 20 & 47.6 \\
\hline Coffee consumption & 27 & $26.7^{*}$ & 37 & $25.0^{*}$ & 32 & 76.2 \\
\hline Folic acid use & 24 & 23.8 & 36 & 24.3 & 11 & 26.2 \\
\hline Use of other food additives & 32 & 31.7 & 50 & 33.8 & 14 & 33.3 \\
\hline Physical activity/sports & 28 & 27.7 & 48 & 32.4 & 16 & 38.1 \\
\hline $\begin{array}{l}\text { Prior hormonal } \\
\text { contraception use }\end{array}$ & 26 & 25.7 & 31 & 20.9 & 10 & 23.8 \\
\hline Regular menstrual cycle & 68 & $67.3^{*}$ & 113 & $76.4^{*}$ & 17 & 40.5 \\
\hline Irregular menstrual cycle & 33 & $32.7^{*}$ & 35 & $23.6^{*}$ & 25 & 59.5 \\
\hline $\begin{array}{l}\text { Sexual intercourse one } \\
\text { time/week }\end{array}$ & 18 & 17.8 & 27 & 18.2 & 7 & 16.7 \\
\hline $\begin{array}{l}\text { Sexual intercourse } 2 \text { times } \\
\text { and more/week }\end{array}$ & 83 & 82.2 & 121 & 81.8 & 35 & 83.3 \\
\hline Past fertility problems & 8 & 7.9 & 6 & 4.0 & 3 & 7.1 \\
\hline $\begin{array}{l}\text { Gynaecological diseases } \\
\text { in the past }\end{array}$ & 3 & 3.0 & 4 & 2.7 & 1 & 2.4 \\
\hline Working status & 93 & 92.1 & 141 & 95.3 & 39 & 92.9 \\
\hline Stress & 60 & 59.4 & 55 & 37.2 & 21 & 50.0 \\
\hline Use of pesticides & 2 & 1.9 & 1 & 0.7 & 1 & 2.4 \\
\hline
\end{tabular}

$\mathrm{n}$ - number of study participants; ${ }^{*} p<0.05$ compared with the Ser/Ser group. For quantitative variables $p$ value by non-parametric ANOVA (Kruskal Wallis), for qualitative variables $p$ value by $x^{2}$ test

conceiving after 12 or more months with the presence of previously mentioned factors are presented in Table 4.

Coffee consumption and low physical activity correlated significantly with fertility problems in the past $(r=$ 0.2 ; $p=0.001$ and $r=0.23 ; p=0.013$ respectively); meanwhile, irregular menstrual cycles correlated with FSHR gene Ser/Ser variant $(r=0.17 ; p=0.008) ; \mathrm{a} \geq 560$ EURO monthly salary and the use of other food additives with older age $(\mathrm{r}=0.17 ; \mathrm{p}=0.008$ and $r=0.27 ; p=0.03$ respectively); as well as living $<10 \mathrm{~km}$ from factories, which correlated with gynaecological diseases $(r=0.18$; $p=0.009$ ); therefore, these factors were excluded from further analysis. The use of contraception prior to pregnancy planning showed no correlation to other factors 


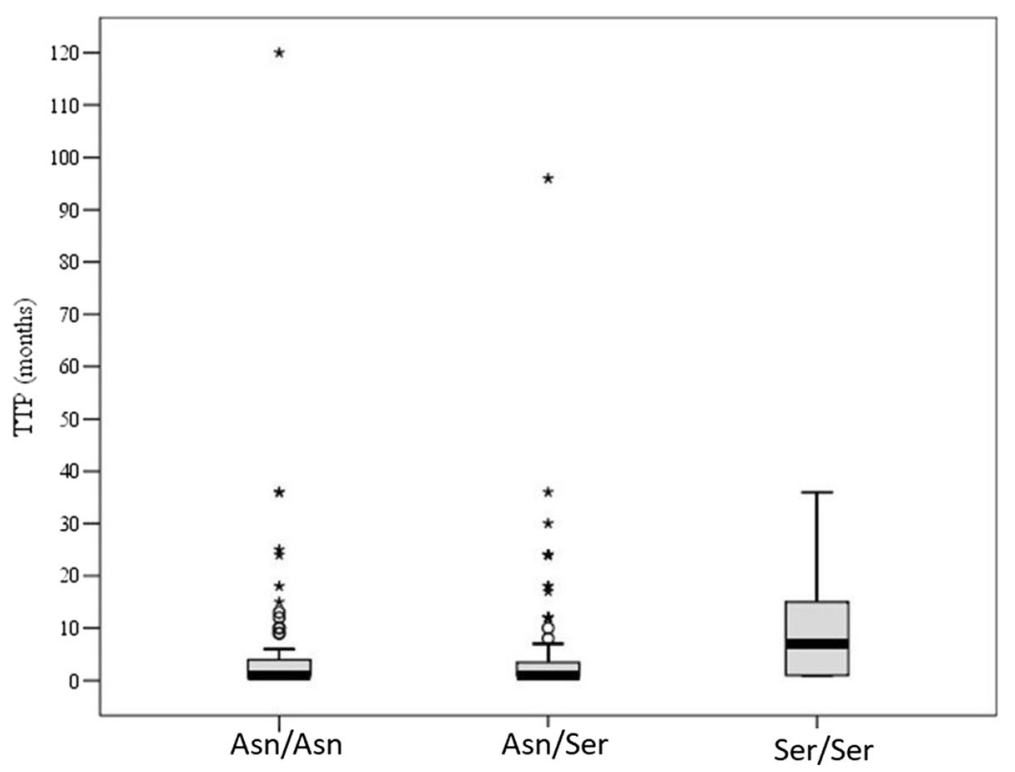

Fig. 1 Distribution of the FSHR polymorphism in TTP groups

from the univariate regression model. The evaluation of significant correlations was done using the Forward Stepwise likelihood ratio method and was referenced to the database. This algorithm converged through 3 steps; selecting: older age ( $\geq 30$ years), the use of any contraception prior to pregnancy planning, previous fertility problems, gynaecological diseases, and the Ser/Ser polymorphism. These were the most significant factors that correctly predicted TTP of 12 or more months (positively classified prognosis was 91.1\%). The combination of these factors formed the multivariate logistic regression model (Table 5). All independent variables were included in the analysis (older age, irregular menstrual cycle, past fertility problems, gynaecological diseases, use of contraception prior to conception, living $<10 \mathrm{~km}$ from factories, and having Ser/Ser polymorphism variant); however, the Forward Stepwise Likelihood ratio method selected the 5 most significant ones (stated above). Accordingly, older age ( $\geq 30$ years), use of any contraception prior to conception, and having gynaecological diseases increased the OR of conceiving after 12 or more months almost by double;

Table 2 Estimated odds ratios for TTP $\geq 12$ months for FSHR genetic variants

\begin{tabular}{llll}
\hline & OR & $95 \% \mathrm{Cl}$ & $P$-value \\
\hline Ser/Ser vs. Asn/Asn & 5.68 & $4.83-6.70$ & $<0.0001$ \\
Ser/Ser vs. Asn/Ser & 4.93 & $4.28-5.68$ & $<0.0001$ \\
Ser/Ser vs. Asn/Asn + Asn/Ser & 5.21 & $4.65-5.85$ & $<0.0001$ \\
\hline
\end{tabular}

$\mathrm{OR}$ - odds ratio, $\mathrm{p}$ - significance level having fertility problems in the past: 1.5 times, and if $\mathrm{Ser} / \mathrm{Ser}$ polymorphism is present: 1.7 times.

\section{Discussion}

The FSHR polymorphism's impact on women's reproductive function has been demonstrated in several studies $[9,11,16,17,23]$; particularly in some diseases, such as the polycystic ovary syndrome and amenorrhea [2426]. Some investigations provide contradictory data on the relationship between single nucleotide polymorphisms, and their link to polycystic ovary syndrome and amenorrhea [27-29]. The main reported findings on changes of hormonal dynamics in women with homozygote mutated $\operatorname{Ser}^{680}$ throughout the menstrual cycle were with lower serum levels of estradiol, progesterone and inhibin A [22]. However, these women had significantly higher FSH levels, and longer menstrual cycles $[12,14,18]$. Patients with the $\mathrm{Ser}^{680} / \mathrm{Ser}^{680}$ genotype are more resistant to FSH action and thus require a stronger stimulus for the same biological response [22]. This finding is important in infertility treatment; patients with the homozygous FSHR $\mathrm{Ser}^{680} / \mathrm{Ser}^{680}$ polymorphism have double the chance of having a resistance to clomiphene citrate [30]. They require higher FSH dosages in order to show the same estradiol response during controlled ovarian stimulation [24]. Furthermore, it was also demonstrated that the frequency of $\mathrm{Ser}^{680} / \mathrm{Ser}^{680}$ variation in the control population is lower than if compared to the infertile women's group [23]. Thus it may be hypothesised that the $\mathrm{Ser}^{680} / \mathrm{Ser}^{680}$ genotype could be directly related to a women's fertility. To our knowledge, the FSHR polymorphism was never investigated in direct relation 
Table 3 Prognostic value of FSHR polymorphism variants for $T$ P $<12$ vs. $\geq 12$ months

\begin{tabular}{|c|c|c|c|c|c|c|}
\hline & \multirow{2}{*}{$\begin{array}{l}\text { Sensitivity } \\
(\%)\end{array}$} & \multirow{2}{*}{$\begin{array}{l}\text { Specificity } \\
(\%)\end{array}$} & \multicolumn{2}{|c|}{ Prognostic value } & \multicolumn{2}{|l|}{ False rate } \\
\hline & & & Positive (\%) & Negative (\%) & Positive (a) & Negative $(\beta)$ \\
\hline Ser/Ser vs. Asn/Asn & 62.50 & 77.31 & 65.71 & 8.91 & 22.69 & 37.50 \\
\hline Ser/Ser vs. Asn/Ser & 50.00 & 83.13 & 49.15 & 10.14 & 16.88 & 50.00 \\
\hline Ser/Ser vs. Asn/Asn + Asn/Ser & 38.46 & 89.29 & 54.78 & 9.64 & 10.71 & 61.54 \\
\hline
\end{tabular}

to TTP in a fertile population. In this study, women were considered to be fertile if they achieved pregnancy without using assisted reproductive technology methods. A large number of factors possibly affecting TTP were investigated along with the FSHR polymorphism in order to detect independent factors predicting longer TTP and to establish the role of FSHR polymorphism between other determinants of women's fertility.

Our data confirmed that higher age, previous gynaecological diseases, and/or fertility problems pose as risk factors for longer TTP. An association for the risk of longer TTP due to hormonal contraception use prior to conception is more questionable. However, an older age of women using contraception could be the reason for this finding.

The relationship of the FSHR polymorphism to the length of the menstrual cycle was demonstrated in our study, as well as in previous publications [22]. Differences in menstrual cycle length between the $\mathrm{Ser}^{680}$ / $\mathrm{Ser}^{680}$ and the $A s n^{680} / \mathrm{Asn}^{680}$ groups result in 12.5 vs. 13.5 menstrual cycles per year, respectively [22]. Assuming no difference in age at the time of menopause; women with the $\mathrm{Ser}^{680} / \mathrm{Ser}^{680}$ genotype would experience 30-40 cycles fewer, than women with an $A s n^{680}$ / $A s n^{680}$ genotype during their reproductive life [22]. Some authors conclude that women with the $\mathrm{Ser}^{680}$, $\mathrm{Ser}^{680}$ genotype have a lower chance to achieve pregnancy during the same time period if compared to the other variants $[23,30]$. Therefore, menstrual periods are stressful events that have certain disadvantages; such as blood loss, menstrual discomfort, and the effects of hormone fluctuations on mood, breast and other

Table 4 Univariate odds ratios for TTP $\geq 12$ months in the group of women analysed for FSHR polymorphism

\begin{tabular}{llll}
\hline Variables $^{a}$ & OR & $95 \% \mathrm{Cl}$ & $\mathrm{p}$ \\
\hline Past fertility problems & 6.97 & $6.22-7.82$ & $<0.0001$ \\
Prior contraception use & 6.43 & $5.74-7.22$ & 0.0043 \\
Irregular menstrual cycle & 4.24 & $3.79-4.77$ & $<0.0001$ \\
Gynaecological diseases in the past & 3.44 & $3.07-3.86$ & 0.0009 \\
Living 10 or less km from factories & 2.06 & $1.84-2.32$ & 0.0399 \\
Age 30 years and older & 1.31 & $1.17-1.47$ & 0.0477 \\
Ser/Ser polymorphism variant & 5.20 & $2.45-11.05$ & 0.0004 \\
\hline p - significance level, OR - odds ratio (unadjusted), Cl- confidence intervals, ${ }^{a}$ \\
- only significative variables were presented in the table
\end{tabular}

oestrogen-dependent organs. This gives rise to some speculation that fewer menstrual cycles during the reproductive lifespan might represent an evolutionary advantage and might influence fertility positively [22]. Our data provide direct evidence that women with the $\mathrm{Ser}^{680} / \mathrm{Ser}^{680}$ genetic variant had a lower chance of conception than females with $A s n^{680} / A s n^{680}$ and $A s n^{680} /$ $\mathrm{Ser}^{680}$ genetic variants.

We have demonstrated that the FSH receptor gene Serine/Serine variant polymorphism is associated with a fivefold lower likelihood to become pregnant during the first 12 months of attempts to conceive.

The other independent factors predicting a TTP of 12 or more months in the study group were older age, gynaecological diseases, fertility problems in the past, and the use of contraception prior to conception.

Some limitations of our study, especially related to the retrospective design, should be discussed. A retrospective design of the study was used in order to achieve a higher participation rate. Only one polymorphism in this region was evaluated, and furthermore, no replication in an independent cohort was attempted. However, it was previously demonstrated that immediately after delivery women can recall the period before conception very well, so data reported here can be treated as reliable [2]. Because of the selected study design, it was not possible to include women who had miscarriages, ectopic pregnancies, or an induced abortion; as well as, to collect information on other important factors that may affect TTP, such as basal FSH levels and semen quality. Moreover, the study was conducted in only one region of the country, which represents one quarter of the entire Lithuanian female population.

Table 5 A multivariate stepwise Enter model describing significant factors for TTP $\geq 12$ months in the group of women analysed for the FSHR polymorphism

\begin{tabular}{llll}
\hline Variables & OR & $95 \% \mathrm{Cl}$ & $P$-value \\
\hline Past fertility problems & 1.568 & $1.16-4.76$ & 0.019 \\
Prior contraception use & 1.871 & $1.14-3.64$ & 0.016 \\
Gynaecological diseases in the past & 2.212 & $1.12-5.74$ & 0.027 \\
Age 30 years and older & 1.952 & $1.25-2.71$ & 0.015 \\
Ser/Ser polymorphism variant & 1.678 & $1.56-2.71$ & 0.007 \\
\hline
\end{tabular}

Constant $=3.741$ 


\section{Strengths and limitations of this study}

- The FSH receptor gene polymorphism may affect human reproduction by causing menstrual cycle disorders.

- The present study demonstrates the effect of FSH receptor gene polymorphism on time to pregnancy" that has not been investigated till now.

- The relationship of FSHr Serine ${ }^{680} /$ Serine $^{680}$ variant polymorphism to lower fecundity can have clinical relevance; e.g. more conservative infertility management can be suggested for women with unexplained infertility having this genetic variant.

- Further studies including prospective studies on the impact of genetic factors on women's fertility are needed.

\section{Conclusions}

Further studies including prospective studies on the impact of genetic factors on women's fertility are needed. Comprehensively study the effects of FSHR polymorphisms on various reproductive traits, the most studied rs6166 SNP should be evaluated together with the rs1394205 in the 5'UTR and with the SNPs in the FSHB locus [31]. However, it is already clear that the relationship of FSHR $\mathrm{Ser}^{680} / \mathrm{Ser}^{680}$ variant polymorphism to lower fecundity can have clinical relevance; e.g. more conservative infertility management can be suggested for women with unexplained infertility whose have this genetic variation.

\section{Abbreviations \\ 5' UTR: 5' untranslated region; Ala: Alanine; Asn: Asparagine; Cl: Confidence interval; FSH: Follicle-stimulating hormone; FSHB: Follicle-stimulating hormone beta subunit; FSHR: Follicle-stimulating hormone receptor; OR: Odds ratios; Ser: Serine; SNP: Single-nucleotide polymorphism; Thr: Threonine; TTP: Time-to-pregnancy}

\section{Acknowledgement}

We hereby express sincere thanks to the staff of the Klaipeda University Hospital for affable conditions for our study. Susan Nieschlag, M.A. deserves special thanks for language editing of the manuscript. We appreciate the ultimate English grammar correction by Mr. Arnold Kincius.

\section{Availability of data and materials}

The original data set is available on individual request by emailing the corresponding author, birute.zilaitiene@Ismuni.lt.

\section{Authors' contributions}

$M D, J G, E N, B Z, R V$, and RO were involved in the concept and design. MD, $J G, E N$, and BZ performed the analyses and $M D, J G, E N, R V$, and RO contributed to the interpretation of the data. MD, BZ and RO drafted the manuscript, and $J G, E N$ and RV provided critical revision. MD, JG, EN, BZ, RV, and RO were involved in the final approval. All authors read and approved the final manuscript.

\section{Ethics approval and consent to participate}

The study was approved by the Lithuanian Bioethics Committee (21/12/2006 No. 59/2). The aim of the survey protocol was carefully explained to each subject of study entry, and a written informed consent was obtained.
Consent for publication

Not applicable.

\section{Competing interests}

All authors declare that they have no competing interest. The authors alone are responsible for the content and writing of the paper.

\section{Publisher's Note}

Springer Nature remains neutral with regard to jurisdictional claims in published maps and institutional affiliations.

\section{Author details}

${ }^{1}$ Institute of Endocrinology, Lithuanian University of Health Sciences, 50009 Kaunas, Lithuania. ${ }^{2}$ Center of Reproductive Medicine and Andrology,

University of Münster, 48149Münster, Münster, Germany.

Received: 13 February 2017 Accepted: 21 June 2018

Published online: 28 June 2018

\section{References}

1. Caserta D, Mantovani A, Marci R, Fazi A, Ciardo F, La Rocca C, et al. Environment and women's reproductive health. Hum Reprod Update. 2011; 17(3):418-33. https://doi.org/10.1093/humupd/dmq061.

2. Joffe M. Feasibility of studying subfertility using retrospective self reports. J Epidemiol Community Health. 1989;43(3):268-74.

3. Baird DD, Wilcox AJ, Weinberg CR. Use of time to pregnancy to study environmental exposures. Am J Epidemiol. 1986;124(3):470-80.

4. Schmidt L, Holstein BE, Christensen U, Boivin J. Communication and coping as predictors of fertility problem stress: cohort study of 816 participants who did not achieve a delivery after 12 months of fertility treatment. Hum Reprod. 2005;20(11):3248-56.

5. Stanford JB, Dunson DB. Effects of sexual intercourse patterns in time to pregnancy studies. Am J Epidemiol. 2007;165(9):1088-95.

6. Gnoth C, Godehardt E, Frank-Herrmann P, Friol K, Tigges J, Freundl G. Definition and prevalence of subfertility and infertility. Hum Reprod. 2005; 20(5):1144-7. https://doi.org/10.1093/humrep/deh870.

7. Huhtaniemi IT, Themmen AP. Mutations in human gonadotropin and gonadotropin-receptor genes. Endocrine. 2005;26(3):207-17.

8. Latronico AC, Arnhold IJ. Gonadotropin resistance. Endocr Dev. 2013;24:25-32. https://doi.org/10.1159/000342496.

9. Levallet J, Pakarinen P, Huhtaniemi IT. Follicle-stimulating hormone ligand and receptor mutations, and gonadal dysfunction. Arch Med Res. 1999;30(6): 486-94. https://doi.org/10.1016/S0188-0128(99)00058-5.

10. Lussiana C, Guani B, Mari C, Restagno G, Massobrio M, Revelli A. Mutations and polymorphisms of the FSH receptor (FSHR) gene: clinical implications in female fecundity and molecular biology of FSHR protein and gene. Obstet Gynecol Surv. 2008;63(12):785-95. https://doi.org/10.1097/OGX. Ob013e31818957eb.

11. Laan M, Grigorova M, Huhtaniemi IT. Pharmacogenetics of folliclestimulating hormone action. Curr Opin Endocrinol Diabetes Obes. 2012; 19(3):220-7. https://doi.org/10.1097/MED.0b013e3283534b11.

12. Achrekar SK, Modi DN, Meherji PK, Patel ZM, Mahale SD. Follicle stimulating hormone receptor gene variants in women with primary and secondary amenorrhea. J Assist Reprod Genet. 2010;27(6):317-26. https://doi.org/10. 1007/s10815-010-9404-9.

13. Achrekar SK, Modi DN, Desai SK, Mangoli VS, Mangoli RV, Mahale SD. Poor ovarian response to gonadotrophin stimulation is associated with FSH receptor polymorphism. Reprod BioMed Online. 2009;18(4):509-15.

14. Desai SS, Achrekar SK, Pathak BR, Desai SK, Mangoli VS, Mangoli RV, et al. Follicle-stimulating hormone receptor polymorphism (G-29A) is associated with altered level of receptor expression in granulosa cells. J Clin Endocrinol Metab. 2011;96(9):2805-12. https://doi.org/10.1210/jc.2011-1064.

15. Simoni M, Nieschlag E, Gromoll J. Isoforms and single nucleotide polymorphisms of the FSH receptor gene: implications for human reproduction. Hum Reprod Update. 2002;8(5):413-21.

16. Falconer $\mathrm{H}$, Andersson $\mathrm{E}$, Aanesen A, Fried G. Follicle-stimulating hormone receptor polymorphisms in a population of infertile women. Acta Obstet Gynecol Scand. 2005;84(8):806-11.

17. de Koning $\mathrm{CH}$, Benjamins $\mathrm{T}$, Harms $\mathrm{P}$, Homburg R, van Montfrans JM, Gromoll J, et al. The distribution of FSH receptor isoforms is related to basal 
FSH levels in subfertile women with normal menstrual cycles. Hum Reprod. 2006;21(2):443-6.

18. Altmäe S, Hovatta O, Stavreus-Evers A, Salumets A. Genetic predictors of controlled ovarian hyperstimulation: where do we stand today? Hum Reprod Update. 2011;17(6):813-28. https://doi.org/10.1093/humupd/dmr034.

19. Genro VK, Matte U, De Conto E, Cunha-Filho JS, Fanchin R. Frequent polymorphisms of FSH receptor do not influence antral follicle responsiveness to follicle-stimulating hormone administration as assessed by the follicular output RaTe (FORT). J Assist Reprod Genet. 2012;29(7):657-63. https:/doi.org/10.1007/s10815-012-9761-7.

20. Klinkert ER, te Velde ER, Weima S, van Zandvoort PM, Hanssen RG, Nilsson $\mathrm{PR}$, et al. FSH receptor genotype is associated with pregnancy but not with ovarian response in IVF. Reprod BioMed Online. 2006;13(5):687-95. https:// doi.org/10.1016/S1472-6483(10)60660-8

21. Son WY, Das M, Shalom-Paz E, Holzer H. Mechanisms of follicle selection and development. Minerva Ginecol. 2011;63(2):89-102.

22. Greb RR, Grieshaber K, Gromoll J, Sonntag B, Nieschlag E, Kiesel L, et al. A common single nucleotide polymorphism in exon 10 of the human follicle stimulating hormone receptor is a major determinant of length and hormonal dynamics of the menstrual cycle. J Clin Endocrinol Metab. 2005; 90(8):4866-72

23. Laven JS, Mulders AG, Suryandari DA, Gromoll J, Nieschlag E, Fauser BC, et al. Follicle-stimulating hormone receptor polymorphisms in women with normogonadotropic anovulatory infertility. Fertil Steril. 2003;80(4):986-92.

24. Simoni $M$, Tempfer CB, Destenaves B, Fauser BC. Functional genetic polymorphisms and female reproductive disorders: part I: polycystic ovary syndrome and ovarian response. Hum Reprod Update. 2008;14(5):459-84. https://doi.org/10.1093/humupd/dmn024.

25. Nakamura Y, Maekawa R, Yamagata Y, Tamura I, Sugino N. A novel mutation in exon8 of the follicle-stimulating hormone receptor in a woman with primary.amenorrhea. Gynecol Endocrinol. 2008;24(12):708-12. https://doi. org/10.1080/09513590802454927. .

26. Gu BH, Park JM, Baek KH. Genetic variations of follicle stimulating hormone receptor are associated with polycystic ovary syndrome. Int J Mol Med. 2010;26(1):107-12

27. Du J, Zhang W, Guo L, Zhang Z, Shi H, Wang J, et al. Two FSHR variants, haplotypes and meta-analysis in Chinese women with premature ovarian failure and polycystic ovary syndrome. Mol Genet Metab. 2010;100(3):292-5. https://doi.org/10.1016/j.ymgme.2010.03.018.

28. Unsal T, Konac E, Yesilkaya E, Yilmaz A, Bideci A, Ilke Onen H, et al. Genetic polymorphisms of FSHR, CYP17, CYP1A1, CAPN10, INSR, SERPINE1 genes in adolescent girls with polycystic ovary syndrome. J Assist Reprod Genet. 2009;26(4):205-16. https://doi.org/10.1007/s10815-009-9308-8.

29. Tong Y, Liao WX, Roy AC, Ng SC. Absence of mutations in the coding regions of follicle-stimulating hormone receptor gene in Singapore Chinese women with premature ovarian failure and polycystic ovary syndrome. Horm Metab Res. 2001;33(4):221-6.

30. Overbeek A, Kuijper EA, Hendriks ML, Blankenstein MA, Ketel IJ, Twisk JW, et al. Clomiphene citrate resistance in relation to follicle-stimulating hormone receptor Ser680Ser-polymorphism in polycystic ovary syndrome. Hum Reprod. 2009;24(8):2007-13. https://doi.org/10.1093/humrep/dep114.

31. Simoni M, Casarini L. Mechanisms in endocrinology: genetics of FSH action: a 2014-and-beyond view. Eur J Endocrinol. 2014;170(3):R91-107. https://doi.org/10.1530/EJE-13-0624.

\section{Ready to submit your research? Choose BMC and benefit from:}

- fast, convenient online submission

- thorough peer review by experienced researchers in your field

- rapid publication on acceptance

- support for research data, including large and complex data types

- gold Open Access which fosters wider collaboration and increased citations

- maximum visibility for your research: over $100 \mathrm{M}$ website views per year

At BMC, research is always in progress.

Learn more biomedcentral.com/submissions 